\title{
Evaluation of the 19 varieties and accessions of tomato against bacterial wilt in Bobo-Dioulasso, Burkina Faso
}

\author{
Oumarou TRAORE ${ }^{1 *}$, Issa WONNI ${ }^{2}$, Fousseni BORO ${ }^{2}$, Etienne SOMTORE $^{3}$, \\ Cyril Tinlé ZOMBRÉ ${ }^{2}$, Oumarou Zoéyandé DIANDA², Emmanuel WICKER ${ }^{4}$, \\ Paul ILBOUDO ${ }^{2}$, Léonard Somgnogdin OUEDRAOGO ${ }^{2}$ and Irénée SOMDA ${ }^{5}$

\footnotetext{
${ }^{1}$ Institut de Recherche en Sciences Appliquées et Technologies, Département Substances Naturelles, 01 BP 2393 Bobo-Dioulasso 01, Burkina Faso.

${ }^{2}$ Institut de l'Environnement et de Recherches Agricoles, Laboratoire de Bactériologie, station de Faroko Bâ, 01 BP 910 Bobo-Dioulasso 01, Burkina Faso.

${ }^{3}$ Ministère de l'Agriculture et des Aménagements Hydrauliques, Secrétariat Général, Centre Agricole Polyvalent de Matourkou.

${ }^{4}$ Unité Mixte de Recherche Interactions Plantes-Microorganismes-Environnement (IPME), CIRAD, équipe GTIPP 911 avenue Agropolis BP 64501343, Montpellier, France.

${ }^{5}$ Université Nazi Boni, Institut du Développement Rural, laboratoire des Systèmes Naturels, Agrosystèmes et de l'Ingénierie de l'Environnement (SyNAIE), 01 BP 1091 Bobo-Dioulasso 01, Burkina Faso.

*Corresponding author; E-mail : oumaroutraor@yahoo.fr; Tel. (+226) 71358850
}

\begin{abstract}
Bacterial wilt caused by Ralstonia solanacearum E. F. Smith is one of the most harmful phytobacteriosis in the world. The search for varieties resistant or tolerant to this disease is the main method of control. However, there is very little information on tomato accessions and varieties deemed resistant or tolerant to the disease in Burkina Faso, hence the resistance assessment of 19 tomato varieties and accessions in the field in order to improve the productivity of tomatoes in Burkina Faso. With respect to varietal screening, a completely randomized Fisher block was used and agromorphological parameters were evaluated. The evaluation has shown that CRA 66, F1 Platinum, NC72TR4-4, Hawaii 7996, BF-Okitsu and FBT4 are more resistant with respective incidences of $1.25 \% ; 1.25 ; 1.47 \% ; 2.50 \% ; 2.95 \%$ and $4.37 \%$; while L390 was the most sensitive $(38.80 \%)$. In terms of production, F1 Platinum, F1 Mongal, FBT3 and FBT4 gave the best net yields of 25.85; 25.47; 20.6 and 20.34 tonnes.ha-1. On the other hand, some accessions (CRA66 and BF-Okitsu), which are less sensitive to the pathogen, gave derisory yields. In view of the results obtained, market gardeners in the city of Bobo-Dioulasso can be advised of INERA varieties FBT3 and FBT4 and the F1 Platinum and F1 Mongal hybrids for their good behavior in terms of resistance to the disease and/or of correct yield in infected soils.
\end{abstract}

(C) 2020 International Formulae Group. All rights reserved.

Keywords: Burkina Faso, R. solanacearum, tomato, varietal resistance.

\section{INTRODUCTION}

Bacterial wilt caused by Ralstonia solanacearum E. F. Smith is one of the most harmful phytobacterioses in the world (Fondio et al., 2010; Mansfield et al., 2012). To control this disease, it is recommended to use fallow or crop rotation of the tomato with other non-host crops (corn, soy, rice, etc.). This technique 
seems to show limits in Burkina Faso because of the land deficit (Kanda et al., 2014). In fact, producers produce the same speculations in continuous monoculture on the same portions of land (Fondio et al., 2013). This practice causes the maintenance and maintenance of the bacteria in the soil. To allow optimal production, selections are made to find varieties that are resistant or tolerant to the disease. The search for resistant or tolerant varieties to bacterial wilt appears the ultimate sustainable remedy indicated to improve tomato productivity (Lebeau, 2010). There is little information on accessions and varieties of tomatoes found to be resistant or tolerant in the context of Burkina Faso, hence the screening of 19 varieties and accessions of tomato in a semicontrolled medium and in the field for their resistance or tolerance to the disease.

\section{MATERIALS AND METHODS \\ Experimental site}

The experimentation was conducted at Kiri, at north of the town of Bobo-Dioulasso at the edge of the Houet Marigot at 11.23211 ${ }^{\circ}$ North Latitude and $4.277719^{\circ}$ West Longitude. Kiri was once famous for its tomato production that supplied Bobo-Dioulasso. Soils are silty to silty clay. The climate is South-Sudanese characterized by a rainy season (May to October) and a dry season (November to April). Cumulative rainfall was $587.1 \mathrm{~mm}$ during the trial period (MayAugust), and average relative humidity was $70.8 \%$. The minimum monthly average temperatures varied between $21.4^{\circ} \mathrm{C}$ and $23.1^{\circ} \mathrm{C}$ during the experiment whereas maximum temperatures ranged from $29.9{ }^{\circ} \mathrm{C}$ to $37.7{ }^{\circ} \mathrm{C}$ (INERA, 2017). The site selected for the trial (Kiri) had a high potential inoculum of $R$. solanacearum $\left(9.810^{5}\right.$ CFU.g ${ }^{-1}$ dry soil).

\section{Materials \\ Plant material}

Plant material is composed of 19 tomato commercial varieties, breeding lines and gene bank accessions (Table 1).

\section{Inputs}

Acarius (Abamectine: 18g. $\mathrm{L}^{-1}$ ) was used against sucking biting insects and mites.
NPK (14-23-14) and urea 46\% were used as mineral fertilizers.

\section{Methods \\ Evaluation of varietal resistance}

The experimental setup is a completely randomized Fisher block with 4 repetitions. An elementary parcel consists of a board $5 \mathrm{~m}$ long and $1 \mathrm{~m}$ wide. The plants were transplanted to the plank in double rows at $0.8 \mathrm{~m}$ between rows and $0.5 \mathrm{~m}$ between plants on the line. The area of basic parcel is $5 \mathrm{~m}^{2}$. The distance between the elementary parcels is $1 \mathrm{~m}$ and that between the blocks is $1.5 \mathrm{~m}$. We are 20 plants on each basic parcel.

The potting soil used for the nursery was taken from Farako-Bâ sandy-loam soil in the $0-15 \mathrm{~cm}$ horizon. Indeed, the Farako-Ba soil is of ferritic type with sandy texture. The loose part obtained after sieving and removal of the impurities was mixed with the organic manure of well decomposed pork (2 wheelbarrows of potting soil for one of organic manure). The well moistened mixture was then sterilized on high heat for 90 minutes. The soil thus sterilized is transferred into two tanks (4 $\mathrm{m} \times 1 \mathrm{~m} \times 0.2 \mathrm{~m}$ ) raised to $0.8 \mathrm{~m}$ from the ground until cooling to then be glided. Seeding was carried out ten (10) days after the biological activity resumed in the substrate. The nursery was watered as needed. Two weeks after sowing, the plants were progressively hardened by a reduction of watering. On the day of transplanting, the nurseries were thoroughly watered to facilitate the uprooting of the plants.

After plow plowing, followed by planning, the experimental setup is put in place. The plants at 21 days after sowing were transplanted. NPK was applied at the rate of $300 \mathrm{~kg} \cdot \mathrm{ha}^{-1}$ in three spreads $(14,30$ and 50 JAR). Urea is applied at $200 \mathrm{~kg} \cdot \mathrm{ha}^{-1}$ in two applications $(30$ and 50 Day After Transplanting) JAR. Experiments were manually weeded before each mineral fertilizer intake. At the last fertilization each row was ridged up.

Furrow irrigation was done to the skate. Phytosanitary sprays against mites and other 
pests were applied every 10 days from full recovery until harvest.

\section{Effect of disease on different varieties and accessions}

From three weeks after transplanting until the first fruits were harvested, the number of wilted plants per elementary plot was recorded weekly. Incidence of wilting (IFB) and disease progression over time were thus evaluated.

$I F B=\frac{\text { number of wilted plants }}{\text { total number of plants }}$

IFB is the bacterial wilt index calculated at several dates (identified by the number of days after transplantation). Plants height and collar diameter were measured at the flowering stage with a graduated ruler and a Vernier caliper, respectively. Flowering dates were recorded when $50 \%$ of the plants in a plot were flowering. Harvested fruits were first weighted for each plot using a scale. After sorting healthy (large / medium size, salable) and damaged (attacked fruits, exploded fruits, small caliber, etc.) fruits were weighted separately.

\section{Data processing}

The data obtained were entered with the Excel spreadsheet version 2013. This spreadsheet was also used to build the graphs. Analysis of variance and principal component analysis (PCA) were performed with XLSTAT software 2007.07.02. The means were compared with the Student Newman Keuls multiple comparison test at the 5\% threshold. The ACP allowed us to present the interactions that can exist between the different variables studied.

Table 1: Characteristics of the 19 tomato varieties / accession tested.

\begin{tabular}{|c|c|c|c|c|}
\hline varieties / accessions & Provenances & Production Cycle & Fruit color & Wilt effect \\
\hline F1 Mongal & Technisem & 65 DAS & Red & Resistant \\
\hline Rossol & Technisem & 65 DAS & Red & Sensitive \\
\hline FBT1 & INERA & 80 DAS & Red & ND \\
\hline FBT2 & INERA & 75 DAS & Red & ND \\
\hline FBT3 & INERA & 70 DAS & Red & ND \\
\hline FBT4 & INERA & 70 DAS & Red & ND \\
\hline NC72TR4-4a & INRA & Indeterminate & Red & Resistant \\
\hline IRATL $3^{\mathrm{a}}$ & INRA & 70 DAS & Red & Resistant \\
\hline TML46 oblong ${ }^{\mathrm{a}}$ & INRA & 70 DAS & Red/Pink & Resistant \\
\hline Hawai $7996^{a}$ & INRA & 75 DAS & Red & Resistant \\
\hline CRA $66^{\mathrm{a}}$ & INRA & Indeterminate & Pink & Resistant \\
\hline BF-Okitsu ${ }^{a}$ & INRA & Indeterminate & Red & Resistant \\
\hline R $3034^{\mathrm{a}}$ & INRA & Semi-determinate & Red & Resistant \\
\hline $\mathrm{L} 285^{\mathrm{a}}$ & INRA & Indeterminate & Red & Resistant \\
\hline CLN1463 ${ }^{\mathrm{a}}$ & INRA & Indeterminate & Red & Resistant \\
\hline Okitsu Sozai $N^{\circ} 1 \mathrm{a}$ & INRA & Indeterminate & Red & Resistant \\
\hline L390a & INRA & Indeterminate & Yellow & Sensitive \\
\hline F1 Platinum & East-West Seeds & 70 DAS & Red & Resistant \\
\hline F1 Padma & East-West -Seeds & 70 DAS & Red & Resistant \\
\hline
\end{tabular}




\section{RESULTS}

\section{Effect of disease on phenological variables}

In Table 2, the recovery rate of varieties ranges from $60 \%$ to $95 \%$. The lowest rate was in the BF-Okitsu variety and the highest in CNL1463 compared to the Rossol susceptible control. The average rate of recovery is $86.62 \%$. About $58 \%$ of the varieties had a recovery rate below average. A significant difference between tomato varieties was observed in plant height, crown diameter and flowering time. The lowest height was obtained by TML46 Oblong $(34.986 \mathrm{~cm})$ and the highest with the L390 variety $(63.46 \mathrm{~cm})$ compared to the sensitive control with a height of $52.85 \mathrm{~cm}$. About $37 \%$ of the varieties are below the average size of $44.90 \mathrm{~cm}$. Stem diameter (at collar level) of the different varieties at flowering ranged from $8.05 \mathrm{~mm}$ (Okitsu Sozai $\mathrm{n}^{\circ} 1$ ) to $11.75 \mathrm{~mm}$. (FBT3), with the sensitive control Rossol positioned among the lowest values $(8.89 \mathrm{~mm})$.

\section{Effect of disease on Yield of tomatoes}

The Table 3 shows the average yields as well as the rate of damaged fruits of the different varieties tested. A significant difference is observed between yields and rates of damaged fruits. The accession Okitsu Sozai $\mathrm{N}^{\circ} 1$ did not produce any fruit. The rate of damaged fruits between varieties varies from $12.85 \%$ (Platinum variety) to $68.25 \%$ (L285), with an average of $27.09 \%$. More than $50 \%$ of the varieties have a rate below average. The varieties selected in Burkina Faso all have a damage rate of less than $20 \%$.

As for the gross yield, it varied from 0.55 tonnes.ha $^{-1}$ (IRATL3) and 11.29 tonnes.ha ${ }^{-1}$ for the susceptible control (Rossol), to 30.01 t.ha $^{-1}$ (F1 Mongal). More than 50\% of the varieties/accessions have a gross yield above the average of 14.53 tonnes.ha ${ }^{-1}$. The local varieties had a gross yield of more than 22 tonnes.ha $^{-1}$. Net yield between varieties varied from 0.45 tonnes.ha $^{-1}$ (IRATL3) to 25.85 tonnes.ha $^{-1}$ (Platinum variety). About $50 \%$ of the varieties/accessions yielded below the average yield of 11.54 tonnes.ha $^{-1}$. Four (4) varieties namely F1 Platinum, FBT3, FBT4 and F1 Padma gave the best yields statistically close to the resistant control F1 Mongal.

\section{Correlations between the studied parameters}

The correlation matrix gives the strength and direction (positive or negative) of relationship between the different parameters studied (Table 4). From this matrix, we find that there is a strong correlation (0.984) between the gross yield and the net yield. However, there is a negative correlation between wilt incidence and crown diameter (0.146).

\section{Sensitivity of tomatoes to bacterial wilt}

Figure 1 shows the histograms of the incidence of disease by variety. At 70 JAR, all varieties of tomato showed signs of bacterial wilt. Significant differences between the 19 tomato varieties/accessions were observed. Wilting rates ranged from $1.25 \%$ to $38.80 \%$. Thus, L390 and Rossol, the susceptible controls, displayed the highest incidence of wilting (38.80\% and $33.25 \%$ respectively). They were followed by FBT2 $(29.44 \%)$ and IRATL3 (14.40\%). In contrast, CRA66 and F1 Platinum were the least susceptible to the disease with a mortality rate of $1.25 \%$.

\section{Progression of the disease over time}

Figure 2 displays the evolution of the disease between 28 and 70 JAR for all tomatoes tested. At 28 JAR less than $50 \%$ of the tomatoes showed symptoms of wilting. The induction of the disease remained late and limited for Mongal F1, NC72TR4-4, FBT3, FBT1, CRA 66, Okitsu Sozai No. 1 and F1 Platinum. For FBT2 and the susceptible controls Rossol and L390, after the onset of the symptoms, there is a rapid evolution of the disease. Between 49 JAR and 56 JAR, all varieties / accessions showed signs of wilting. Wilting stabilization is observed for the majority of the varieties / accessions from 63 JAR. Only L390, Rossol, FBT2 and to a lesser extent IRATL 3 continued to wilt until the end of the observations. 
Table 2: Characteristics of phenological variables.

\begin{tabular}{|c|c|c|c|}
\hline Varieties/accessions & Recovery rate (\%) & Plant height (cm) & $\begin{array}{l}\text { Collar diameter } \\
(\mathbf{m m})\end{array}$ \\
\hline F1 mongal & 86,25 & $41,66 \mathrm{bc}$ & $11,44 \mathrm{a}$ \\
\hline Rossol & 78,75 & $52,86 \mathrm{abc}$ & 8,89 bcde \\
\hline FBT1 & 87,50 & $37,02 \mathrm{c}$ & $11,71 \mathrm{a}$ \\
\hline FBT2 & 88,75 & $39,31 \mathrm{c}$ & 10,46 abcd \\
\hline FBT3 & 86,25 & $35,46 \mathrm{c}$ & $11,76 \mathrm{a}$ \\
\hline FBT4 & 85,00 & $35,04 \mathrm{c}$ & $11,04 \mathrm{ab}$ \\
\hline NC72TR4-4 & 90,00 & $56,81 \mathrm{ab}$ & 9,69 abcde \\
\hline IRATL3 & 83,75 & $35,90 \mathrm{c}$ & $8,56 \mathrm{de}$ \\
\hline TML46 oblong & 83,75 & $34,99 \mathrm{c}$ & $8,07 \mathrm{e}$ \\
\hline Hawaï 7996 & 91,25 & $43,12 \mathrm{bc}$ & 9,03 bcde \\
\hline CRA 66 & 80,00 & $52,51 \mathrm{abc}$ & $10,86 \mathrm{abc}$ \\
\hline BF-Okitsu & 60,00 & $58,37 \mathrm{a}$ & $10,74 \mathrm{abcd}$ \\
\hline R 3034 & 80,00 & $40,83 \mathrm{bc}$ & 9,06 bcde \\
\hline L285 & 72,50 & $60,03 \mathrm{a}$ & $11,59 \mathrm{a}$ \\
\hline CLN1463 & 95,00 & $42,34 \mathrm{bc}$ & $10,27 \mathrm{abcd}$ \\
\hline Okitsu Sozai $N^{\circ} 1$ & 73,75 & $43,76 \mathrm{bc}$ & $8,06 \mathrm{e}$ \\
\hline L390 & 87,50 & $63,47 \mathrm{a}$ & 8,70 cde \\
\hline F1 Platinum & 90,00 & $38,17 \mathrm{c}$ & $11,37 \mathrm{a}$ \\
\hline F1 Padma & 88,75 & $41,57 b c$ & $10,40 \mathrm{abcd}$ \\
\hline Moyenne & 83,62 & 44,90 & 10,08 \\
\hline $\mathrm{CV}(\%)$ & 17,45 & 24,80 & 14,95 \\
\hline E-C & 14,60 & 11,14 & 1,51 \\
\hline $\mathrm{R}^{2}$ & 0,30 & 0,68 & 0,69 \\
\hline
\end{tabular}

Column numbers assigned the same letter do not differ significantly at the 5\% threshold (Newman-Keuls Test).

Table 3: Yields and levels of damaged fruits of the varieties tested.

\begin{tabular}{|c|c|c|c|}
\hline Varieties/accessions & $\begin{array}{l}\text { Gross yield } \\
\left(\text { Tonnes.ha }^{-1}\right)\end{array}$ & $\begin{array}{l}\text { Rendement net } \\
\left(\text { Tonnes.ha }^{-1}\right)\end{array}$ & $\begin{array}{l}\text { Rate of damaged fruits } \\
(\%)\end{array}$ \\
\hline F1 Mongal & $30,011 \mathrm{a}$ & $25,47 \mathrm{a}$ & $16,51 \mathrm{ab}$ \\
\hline Rossol & $12,95 \mathrm{bcd}$ & 11,30 bcde & $18,74 \mathrm{ab}$ \\
\hline FBT1 & $22,85 \mathrm{ab}$ & $18,60 \mathrm{ab}$ & $19,24 \mathrm{ab}$ \\
\hline FBT2 & $23,51 \mathrm{ab}$ & $19,47 \mathrm{ab}$ & $16,54 \mathrm{ab}$ \\
\hline
\end{tabular}




\begin{tabular}{llll} 
FBT3 & $24,73 \mathrm{ab}$ & $20,60 \mathrm{ab}$ & $16,23 \mathrm{ab}$ \\
FBT4 & $24,03 \mathrm{ab}$ & $20,35 \mathrm{ab}$ & $16,25 \mathrm{ab}$ \\
NC72TR4-4 & $2,80 \mathrm{~cd}$ & $2,30 \mathrm{cde}$ & $52,45 \mathrm{ab}$ \\
IRATL3 & $0,55 \mathrm{~d}$ & $0,45 \mathrm{de}$ & $16,67 \mathrm{ab}$ \\
TML46 oblong & $16,09 \mathrm{abc}$ & $11,27 \mathrm{bcde}$ & $34,40 \mathrm{ab}$ \\
Hawaï 7996 & $22,84 \mathrm{ab}$ & $14,98 \mathrm{abc}$ & $35,78 \mathrm{ab}$ \\
CRA 66 & $6,43 \mathrm{~cd}$ & $4,49 \mathrm{cde}$ & $29,60 \mathrm{ab}$ \\
BF-Okitsu & $0,91 \mathrm{~d}$ & $0,66 \mathrm{de}$ & $39,28 \mathrm{ab}$ \\
R 3034 & $21,28 \mathrm{ab}$ & $14,14 \mathrm{abcd}$ & $34,56 \mathrm{ab}$ \\
L285 & $1,23 \mathrm{~d}$ & $0,50 \mathrm{de}$ & $68,25 \mathrm{a}$ \\
CLN1463 & $10,74 \mathrm{bcd}$ & $8,63 \mathrm{bcde}$ & $22,56 \mathrm{ab}$ \\
Okitsu Sozai $\mathrm{N}^{\circ} 1$ & $0,00 \mathrm{~d}$ & $0,00 \mathrm{e}$ & $0,00 \mathrm{~b}$ \\
L390 & $2,30 \mathrm{~cd}$ & $1,45 \mathrm{de}$ & $46,11 \mathrm{ab}$ \\
F1 Platinum & $29,81 \mathrm{a}$ & $25,86 \mathrm{a}$ & $12,85 \mathrm{ab}$ \\
F1 Padma & $23,11 \mathrm{ab}$ & $18,71 \mathrm{ab}$ & $18,73 \mathrm{ab}$ \\
\hline Moyenne & 14,53 & 11,54 & 27,09 \\
EC & 12,16 & 10,28 & 25,99 \\
CV (\%) & 33,70 & 39,10 & 45,90 \\
R & 0,77 & 0,75 & 0,38 \\
The averages in a column followed by the same letter are not different according to the Newman Keuls test at the $5 \%$ threshold.
\end{tabular}

Table 4: Pearson correlation matrix between the evaluated parameters.

\begin{tabular}{lllllll}
\hline Settings & Necdiam & Hplt & Groyie & Neyie & Ratdam & IFB \\
\hline Necdiam & 1 & & & & & \\
HPLT & $-0,103$ & 1 & & & & \\
Groyie & 0,308 & $-0,509$ & 1 & & & \\
$\quad$ Netyie & 0,345 & $-0,500$ & 0,984 & 1 & & \\
Ratdam & 0,001 & 0,316 & $-0,302$ & $-0,360$ & 1 & \\
IFB & $-0,146$ & 0,217 & $-0,030$ & $-0,012$ & 0,128 & 1 \\
\hline
\end{tabular}

Necdiam: Collar diameter; Hplt : plant height, Groyie : Gross yield ; Neyie : Net yield; Ratdam : Rate of damaged fruits; IFB : Incidence of Bacterial Wilt. 


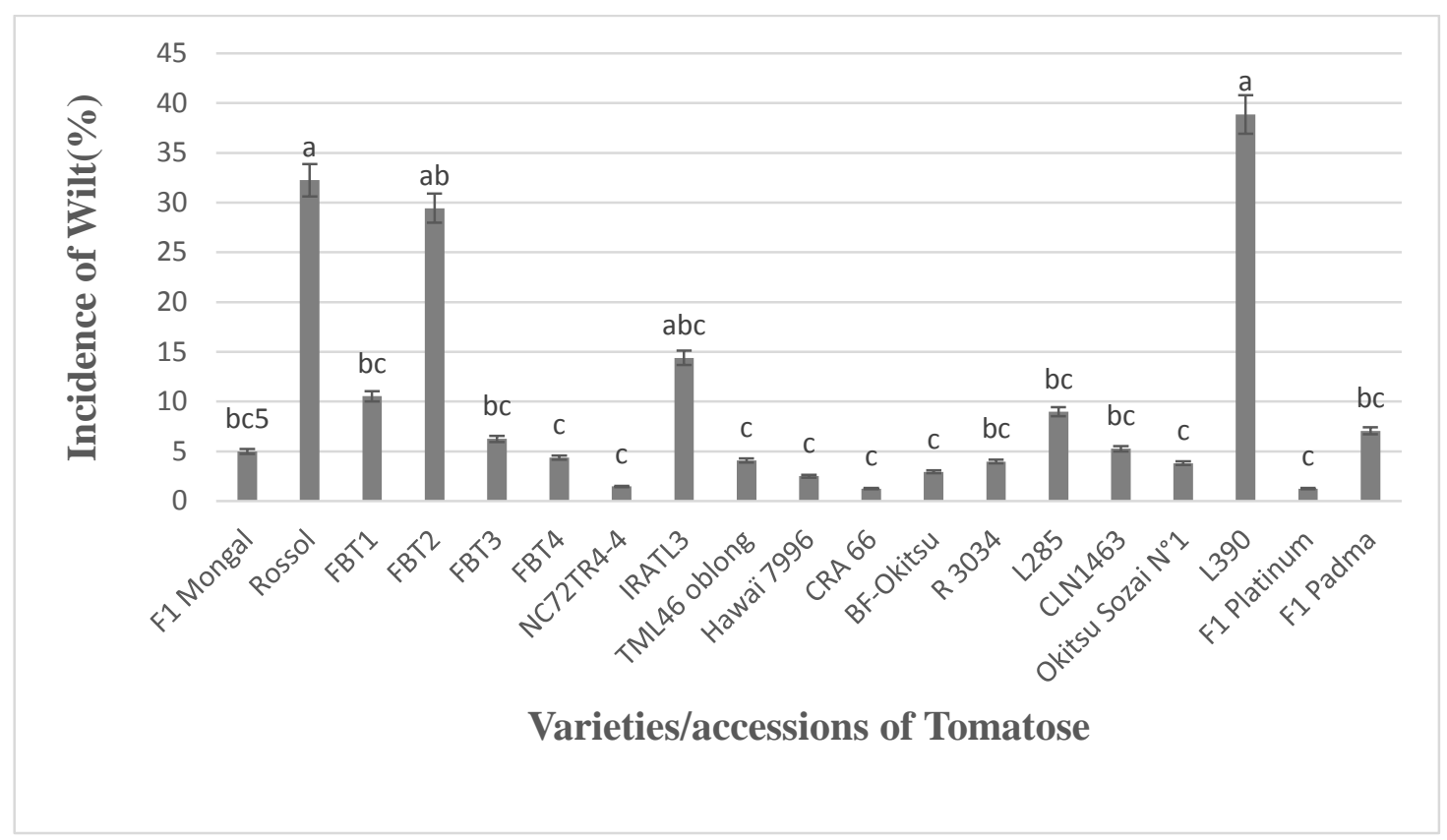

Figure 1: Incidence of bacterial wilt at $70 \mathrm{JAR}$.

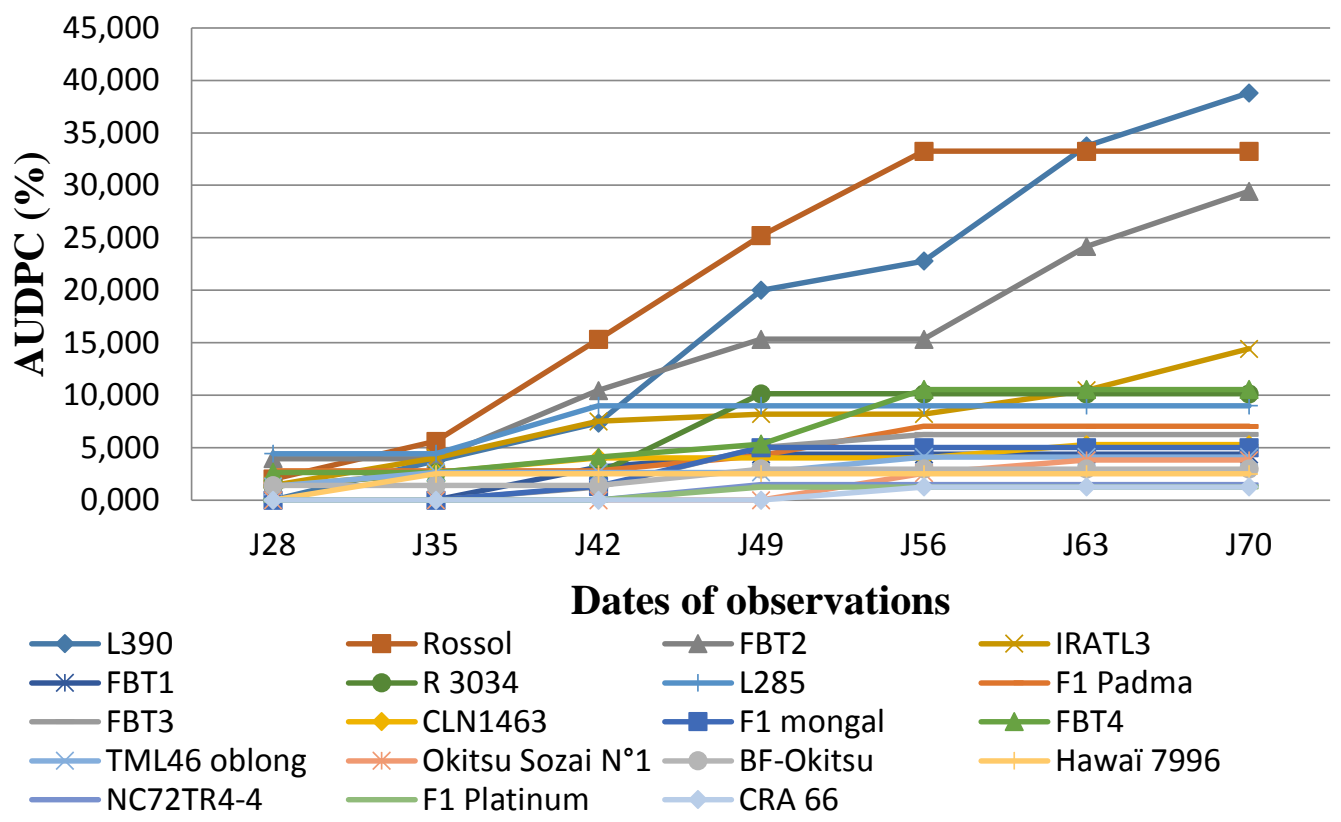

Figure 2: Progression of bacterial wilt over time. 


\section{DISCUSSION}

The bad recovery of some accessions like BF-Okitsu, L285, Okitsu Sozai $N^{\circ} 1$ from INRA Is probably due to the inadaptation of these lines to the agro-climatic conditions of Burkina Faso. Unexpectedly, other imported accessions like F1 Platinum, NC72TR-4, Hawaii 7996 and CLN1463 behaved better than the local varieties. The significant differences among varieties observed for plant collar diameter are probably due to varietal (genetic) differences for plant vigor. Noticeably local varieties tend to be more robust (larger stem diameter) than the other varieties. This result corroborates that obtained by (Nikiéma, 2016) who found that out of fourteen tomato varieties screened in the field, only varieties FBT1 and FBT4 were the most vigorous. As for the height of the plants, the significant difference observed is related to the precocity of the variety. Indeed, the more the variety has a short cycle, the smaller it is.

As expected, the incidence of the disease is stronger on the susceptible controls L390 and Rossol (Figure 2). Rossol seems to have tolerated the disease better than L390 from 56 DAR, with a stabilized wilting. Nikiéma (2016) has shown that Rossol is very sensitive with an incidence rate of more than $40 \%$. There are no standard thresholds for assessing plant resistance to bacterial wilt. Adamou (2011) considers that a potato variety with an incidence rate of $9 \%$ is tolerant, it would be sensitive to $19.05 \%$ and very sensitive from $38 \%$.

Moreover, Wang et al. (1997) estimated that a variety with an incidence of $11 \%$ is resistant, it would be intermediate from $57 \%$, and very sensitive from $90 \%$, (N'Guessan et al., 2012), have shown that there are different levels of plant behavior to bacterial wilt ranging from highly susceptible to high resistance levels in Ivory Coast. The wilting incidence of our varietal sampling indicates that CRA 66, F1 Platinum, NC72TR4-4, Hawaii 7996, BF-Okitsu, Okitsu Sozai No. 1,
TML46 oblong, and FBT4 displayed the highest resistance levels (wilt $>=5 \%$ ) to bacterial wilt. Except FBT4, these varieties were bred for resistance to bacteria wilt and the resistance of several of them (Hawaii 7996, BF-Okitsu, TML 46 oblong) was confirmed in multilocal experiments in different agroecological zones (Wang et al., 2000). The tomatoes FBT1, FBT3, F1 Padma CLN1463, R3034 and L285 displayed a wilt incidence statistically similar to the resistant control F1 Mongal. Fondio et al. (2013) identified three other lines as resistant as Mongal F1 in southern Ivory Coast. The evolution curves of the incidence of the disease (AUDPC) show a plateau for the majority of varieties from 56 DAT (Figure 3). This situation could be explained by the age of the plants which would be old enough for expressing their resistance potential and stabilizing their symptoms. Indeed, according to Winstead and Kelman (1952), resistance increases with age.

On yield components, there is a strong correlation ( $\mathrm{R}=0.984)$ between net return (net yield) and gross return (gross yield). The net yield is negatively correlated with the rate of damaged fruits. As a result, varieties with high levels of damaged fruit have the lowest yield. This result confirms that of (Fondio et al., 2013) which shows that fruit discards explain the low levels of net yields of certain varieties. The high rate of damaged fruit is linked to blossom end rot favorized by rains; fruits perforation by insects and undersized fruits. Indeed, Krid and Messati (2013) reported that abandoned tomato plants generally provide abundant tillers, but belated berries. The low yields of some varieties cannot be explained by the sole disease strong incidence. Indeed, some varieties like CRA 66, and NC72TR4-4 ranking among the most resistant ones gave almost null yields. This low yield would be linked to the ability of the varieties to produce under the same conditions. This result is in agreement with that of (Djidji et al., 2010), who showed that the difference in yield observed 
during a season is due to the variety alone in healthy soil.

\section{Conclusion}

Varietal tomato screening in relation to the soil infectious potential allowed us to detect tomato varieties with high yield potential and resistant to $R$. solanacearum. The varieties CRA 66, Platinum F1, NC72TR4-4, Okitsu Sozai ${ }^{\circ}$ 1, BF-Okitsu and FBT4 showed less symptoms of wilting with rates of less than 5\%. In contrast, the L390, Rossol and FBT2 varieties were the most susceptible to the disease. Among the INERA tomato varieties, FBT3 was the most resistant and productive. The results obtained show that the genetic parameters of tomatoes tested influence the manifestation of the disease. Given our results were obtained only in a few agro-climatic areas of Burkina Faso. Further screenings in other areas of the country are necessary in order to identify the best varieties and to propose them to growers. Our hypotheses are confirmed. Indeed, $R$. solanacearum was identified in all soil samples and six (06) on 19 varieties recorded a low incidence of the disease.

\section{COMPETING INTERESTS}

The authors declare that they have no competing interests.

\section{AUTHORS' CONTRIBUTIONS}

OT conducted field survey, data collection and prepared the original draf. IW, FB and ES they helped in implementing the trial and collecting the data. TCZ and ZOD helped in data analysis. EW contributed to obtaining tomato seeds; PI realized the nurseries and phytosanitary treatments. LSO and IS have approved the sampling methodology validated the data analysis and reviewed the manuscript.

\section{ACKNOWLEDGMENTS}

The authors express their sincere thanks to the ARES-CCD through the PARADE project and all the structures and institutions involved in its implementation, for their financial and material support. In particular, the authors thank Marie-Christine BrandDaunay of INRA (Genetics and Improvement of Fruits and Vegetables) and East-West Seeds for seeds supply.

\section{REFERENCES}

Adamou I. 2011. Caractérisation des souches locales de Ralstonia solanacearum (E. F. Smith) : Évaluation du comportement de six variétés de pomme de terre (Solanum tuberosum L.) face à la souche RS09-76, au Niger. Thèse de Doctorat, Université de Ouagadougou, Burkina Faso, 197p.

Djidji AH, Zohouri GP, Fondio L, Nzi JC, N'Guessan C. 2010. Effet de l'abri sur le comportement de la tomate (Solanum lycopersicum L.) en saison pluvieuse dans le Sud de la Côte-d'Ivoire. Journal of Applied Biosciences, 25: 1557-1564.

Fondio L, Djidji HA, N'Gbesso MFP, Koné D. 2013. Evaluation de neuf variétés de tomate (Solanum Lycopersicum L.) par rapport au flétrissement bactérien et à la productivité dans le Sud de la Côte d'Ivoire. International Journal of Biological and Chemical Sciences, 7(3): 1078-1086.

DOI: http://dx.doi.org/10.4314/ijbcs.v7i3.15.

Fondio L, Djidji AH, N'Gbesso MFDP, Ochou OG. 2010. Évaluation des variétés de tomate et piment pour la tolérance au flétrissement bactérien, et multiplication des semences de piment. Rapport d'activités, Convention CNRA/AVRDC, CNRA, Bouaké, Côte d'Ivoire, 31p.

INERA. 2017. Données météorologiques de la Station de Farako-Bâ, Burkina Faso. INERA, Burkina Faso.

Lebeau A. 2010. Résistance de la tomate, l'aubergine et le piment à Ralstonia solanacearum: interactions entre les géniteurs de résistance et la diversité bactérienne, caractérisation et 
cartographie des facteurs génétiques impliqués chez l'aubergine. Thèse de doctorat, Université de la Réunion, 226p.

Kanda M, Akpavi S, Wala K, Boundjou G, Akpagana K. 2014. Diversité des espèces cultivées et contraintes à la production en agriculture maraîchère au Togo. International Journal of Biological Chemical Sciences, 8(1): 115-127. DOI: http://dx.doi.org/10.4314/ijbcs.v8i1.11

Krid K, Messati S. 2013. Efficacité de la résistance de six variétés de la tomate à Tuta absoluta sous abris plastique à l'ITDAS de Hassi Ben Abdellah (Ouargla). Mémoire de master académique, Université KASDI MERBAH OUARGLA d'Alger, Algérie, $121 \mathrm{p}$.

Mansfield J, Genin S, Margori S, Citovsky V, Sriariyanum M, Ronald P, Dow M, Verdier V, Beer SV, Machado MA, Tothi I, Salmond G, Foster GD. 2012. Top 10 plant pathogenic bacteria. Molecular Plant Pathology, 13: 614-629. DOI : 10.1111/j.1364-3703.2012.00804.x.

N'Guessan CA, Abo K, Fondio L, Chiroleu F, Lebeau A, Poussier S, Wicker E, Koné D. 2012. So near and yet so far: the specific case of Ralstonia solanacearum populations from Côte d'Ivoire in Africa. Phytopathology, 102: 733-740. DOI : 10.1094/PHYTO-11-11-0300.

Nikiéma JC. 2016. Évaluation de la résistance de 14 variétés et accessions de tomate au flétrissement bactérien causé par Ralstonia solanacearum en liaison avec le potentiel infectieux du sol. Mémoire de Fin de cycle des Ingénieurs d'Agriculture CAP-M, Burkina Faso, 74 p.

Wang JF, Thoquet P, Olivier J, Grimsley N. 1997. Genetic analysis of quantitative resistance loci (QRL) of tomato variety Hawaii 7996 in Taiwan. In: Bacterial wilt disease, Molecular and ecological aspects, Prior $\mathrm{PH}$, Allen C, Elphinstone J (Ed.). Gosier: Guadeloupe, France; 245249.

Wang JF, Olivier J, Thoquet $\mathrm{P}$, Mangin B, Sauviac L, Grimsley NH. 2000. Resistance of tomato line Hawaii7996 to Ralstonia solanacearum Pss4 in Taiwan is controlled mainly by a major strain specific locus. Molecular Plant-Microbe Interaction, 13: 6-13. DOI: 10.1094/MPMI.2000.13.1.6. 